\title{
Creating Legal Facts: Indigenous People versus State Plantation Companies in Medan, Indonesia ${ }^{1}$
}

\author{
Wina Khairina ${ }^{2}$ and Christian Lund ${ }^{3 *}$
}

Received: 24 January 2020 | Accepted: 15 May 2020 | Published: 10 June 2020

\begin{abstract}
This paper examines how a local community has tried to legalise its possession of land in the outskirts of the city of Medan, Indonesia. In the absence of accessible legal pathways and in the face of state and gang violence, the community has resorted to an imaginative mimicry of legal land access procedures. This paper argues that law-making does not exclusively originate from the state, but also from society, and as such the community has effectively created legal facts. Data were collected through interviews and long-term contact with the community.
\end{abstract}

Keywords: land occupation, legalisation, urban property, Medan

\section{Introduction}

Land conflicts between smallholders and plantations are ubiquitous in Indonesia, no more so than in the historical 'plantation belt' around Medan in North Sumatra. Peasant and indigenous movements have attempted to use occupations to take back plantation land. Although the government has identified such occupations as illegal, the movements and local residents have attempted to legalise them. Organising themselves in conformity with their understandings of formal government norms, occupants have given their possession an air of legality. People who believe they have rights, but lack rightful means of exercising them, effectively create legal facts by improvising and mimicking legal arrangements. This process takes many mundane forms in everyday interactions, but let us start with one of the more ostentatious events.

In March 2017, AMAN (Aliansi Masyarakat Adat Nusantara, The Indigenous Peoples Alliance of the Archipelago) held its $5^{\text {th }}$ congress in

\footnotetext{
${ }^{1}$ The research for this paper has benefitted from generous funding of the Danish Research Council and the European Research Council (ERC). ERC Grant: State Formation Through the Local Production of Property and Citizenship (Ares (2015)2785650 - ERC-2014-AdG - 662770-Local State). This article is the result of long-term collaboration, joint fieldwork, data collection, and many discussions. Authorship is shared equally.

2 Hutan Rakyat Institute (HaRI), Southeast Asia Institute for Forest and People Studies, Medan, Indonesia.
}

${ }^{3}$ University of Copenhagen, Denmark. *Corresponding author. 
Kampong Tanjung Gusta, in Medan, North Sumatra. This was a great achievement for the indigenous peoples of BPRPI Kampong Tanjung Gusta, ${ }^{4}$ as this national event not only shone light on the village and its population as a part of the indigenous peoples' movement but took place on land that the movement had repossessed from a plantation company. The AMAN congress, which marked the alliance's seventeenth year working with indigenous communities, was attended by approximately 4,000 people, including representatives of indigenous communities worldwide, ministry officials, and local government heads. The Governor of North Sumatera issued a statement endorsing the legalisation of Tanjung Gusta, and AMAN closed the five-day congress with a pact on Kampong Tanjung Gusta (Maklumat Tanjung Gusta).

This kampong was, in effect, an illegal settlement on plantation land; the government claims that according, to law, the land was rightfully leased out to the plantation and thus the kampong was not supposed to be there. Over time, however, Medan has grown and Tanjung Gusta has developed from a rural settlement in a plantation into a largely suburban

\footnotetext{
${ }^{4} \mathrm{BPRPI}$, better known as Rakyat Penunggu, is a social movement that consists of the indigenous people from the Ular River and Wampu River basins. Members of BPRPI Kampong Tanjung Gusta come from the twenty-one kampong that have existed in HGU PTPN II in Medan City, Deli Serdang Regency, and Langkat Regency since political reform.
}

${ }^{5} \mathrm{OKP}$ is a broad category, including a range of organisations from boy scouts to violent entrepreneurs engaged in protection rackets, enforcing the will of those who pay, and sometimes operating in an autonomous fashion. In this paper, we refer only to those neighbourhood. Over the course of this urbanisation, many actors have developed interest in using the land occupied by the Tanjung Gusta community. With such increased competition, the risk of evictions has grown. Many have tried to remove the settlement and its residents over the years, and threats have often come from gangs known collectively as OKP (Organisasi Kemasyarakatan Pemuda/Youth Community Organisations). ${ }^{5}$

The so-called 'plantation belt' in North Sumatra developed in the 1860s, when a new agrarian order (with labour transported from Java and other places) created an economy based on tobacco, sugar, and oil palm plantations. Since then, political tension between planters, workers, and peasants has remained high, peaking during moments of political crisis; the postindependence social revolution in the 1940s, the nationalisation of the 1950s, Suharto's take-over in 1965, and Reformasi in 1998 have all been moments when rules and rights were challenged and unsettled (Damanik, 2016; Lund, in press; Ikhsan, 2014; Pelzer, 1957, 1978, 1982; Rasmussen \& Lund, 2018; Reid, 1979; Stoler 1985a, b, 1988). Land occupations and evictions

OKP that are mobilised for political violence. In North Sumatra and Medan, the most significant include Pemuda Pancasila (Youth of the Five Principles of the Nation), IPK (Ikatan Pemuda Karya, Association of Working Youths), AMPI (Angkatan Muda Pembaharuan Indonesia, Indonesian Youth Force for Renewal), Pam Swakarsa (Swakarsa Public Security Force, formed by the military in 1998) and FKPPI (Forum Komunikasi Putra Putri Indonesia, Communication Forum for Indonesia's Sons and Daughters of Indonesian Veterans, mainly consisting of the children of police and army officers). For more history, see Hadiz (2010) and Wilson (2015). 
thus have a long history in Indonesia. ${ }^{6}$ Over the past couple of decades, land ownership and control have been significantly challenged in many parts of Indonesia. During the late 1990s, agrarian protest became ever more frequent as the Suharto regime-the New Order-spiralled into decline and crisis. Different social organisations, groups, and movements formed in a period of political transformation in Indonesia. Democratisation and decentralisation appeared to offer opportunities to transform society and not least the agrarian structures. These protests were accompanied by land occupations by farmers, who seized land (which had previously been farmed by smallholders and before that had been controlled by Dutch colonial authorities and plantations) from state forests or from private and government plantations (Lund \& Rachman, 2016). It is in this context the following case plays out.

\section{Occupation and Legalisation}

In this article, we examine one of the many land occupations in Indonesia from a particular perspective. People have felt it their right to 'take back', as it were, the land that had at one point been taken from them (and their ancestors) by the colonial or Indonesian governments. On the one hand, these occupations were condoned and even hailed by popular movements as the realisation of the long-awaited land reform embedded in 1960's Basic Agrarian Law, which had never actually been fully implemented. On the other hand, forest and plantation owners-as well as the Ministry

\footnotetext{
${ }^{6}$ For a general picture, consult Bachriadi (2010), Fauzi \& Bachriadi (2006), Langenberg (1982), Lucas \& Warren (2013), Khairina $(2013,2015)$,
}

of Forestry and Agriculture-condemned the occupations as theft (Fauzi \& Bachriadi, 2006; Lucas \& Warren, 2013). The people of Tanjung Gusta, and Indonesia in general, have therefore faced a difficult problem. As with most ordinary people, they have no desire to be criminals or outlaws. However, they recognise that government institutions will likely not see these occupations as legal or even legitimate. Ultimately, the inhabitants of Tanjung Gusta have engaged in activities to persuade the authorities, the public, and themselves of the legality of their claims. They aim to create legal facts.

The creation of effective legal facts take place not only in legislative assemblies and government offices, but also on the ground when people aim to make claims look like rights and turn possession onto property. The point of legalisation is to bestow a rule or claim an air of legality. The legalisation of property, therefore, is the successful persuasion that claims to land and other resources are legal in form or substance, regardless of whether these claims and statutory laws correspond. Legal posturing, through which the state and its law are mimicked, can produce the effect of legality (Lund, in press). One may legalise illegal acts and claims while quashing established rights, as long as the operation is sustained with reference to law (Rose, 1994; Mitchell, 2002; Das, 2007; Campbell, 2015).

Successfully persuading the relevant public and authorities of the legality of claims, and having them recognise these claims as rights, involves performance. People who believe that they have rights,

McCarthy \& Robinson (2016), Pelzer (1978, 1982), Rachman (2011), and Winayanti (2010).

PCD Journal Vol. 8 No. 1 (2020) 
but who have no rightful means of exercising them, improvise and mimic legal arrangements. Most people learn about the law not by comprehensive study or through experts, but through individual experiences of diagnostic events that reveal interests, arguments, and settlements of conflicts (Krier, 1994; Moore, 1987). Often peopleincluding government representativesrefer to the law with a rather minimal knowledge of actual formal legislation. Instead, they refer to doctrines and precedents as they imagine or recollect them, adapting them to the actual circumstance (Kunz et al., 2016). In societies where the state claims legal hegemony, as in Indonesia, we should, as Benton (2012, p. 29) points out, expect people to 'actively reference state law, however inaccurately or opportunistically'. Indonesian land legislation remains a thicket of permissions and restrictions, competing rights and overlapping jurisdictions, and many land rights seem equivocal. Fundamental ambiguities of ownership and entitlements, wrapped in a web of administrative and legal rules and exceptions, have often made it virtually impossible to rationally disentangle competing claims (Fitzpatrick, 2006; see also Holston, 1991). In this context of a violent and powerful state and ambiguous legal pluralism, many have pursued a strategy of defining claims that somehow align with (one of the many competing) statutory legal principles and to solicit (one of the many competing) government institutions for recognition. People shop for institutions to recognise their claims, and institutions of authority also shop for controversies to settle and claims to grant (Benda-Beckmann, 1981). In this way, both claimants and authorities look for mutual visibility; for mutual recognition. The analysis that follows offers several examples of how ordinary people attempt to become visible to relevant authorities to whom they would otherwise be invisible. More specifically, we examine the legalisation strategies employed by the indigenous people of Rakyat Penunggu Kampong Tanjung Gusta in their fight for legal recognition of what they perceive as their customary territories.

\section{Methods}

Research was conducted between 2015 and 2017 using qualitative methods. It began with a literature study, field visits, in-depth interviews with key informants in North Sumatra, as well as focus group discussions with members of BPRPI Kampong Tanjung Gusta A and B. The authors also had the opportunity to conduct participatory observations and interviews with Rakyat Penunggu in their preparations for the $5^{\text {th }}$ AMAN congress.

\section{Legalising Land Control in Tanjung Gusta}

The area of Tanjung Gusta, some 1,900 hectares, bestrides the Regency of Deli Serdang and the Municipality of Medan. Previously, this area was part of a huge European plantation named Helvetia (created in 1870), which later gave name to an urban neighbourhood. During the nationalisation of Dutch property in 1958, the newly formed peasant movement BPRPI (Badan Perjuangan Rakyat Penunggu Indonesia, Indonesian Watchmen's Agency) occupied some of the 
land, known as Tanjung Gusta. ${ }^{7}$ BPRPI's members fall into three groups, namely Mastautin, Semenda and Resam. Mastautin are the descendants of those who first cleared the forest and built a village. Semenda are those descended from marriages between migrants and Mastautin. Finally, the Resam are descended from migrants who registered with village officials and declared that they were willing to obey BPRPI's organisational rules. In this way, BPRPI sought to control migration to the area. However, as migration has increased, the Mastautin have become outnumbered by Semenda and Resam. As of 2018, Tanjung Gusta is inhabited by some 24,000 people.

During the 1950s, BPRPI had difficulties establishing itself as the area's predominant movement. ${ }^{8}$ In that period, other peasant groups also claimed the land, and it was impossible to gauge the government's position on land occupations. While occupations had been encouraged by the revolutionary government, in the 1950s the government and the army tried to limit such occupations (Pelzer, 1982) (anonymous veteran members of BPRPI, personal communication, November 2016). In the early 1960s BPRPI and its members controlled some 340 hectares of land in Tanjung Gusta; the remaining 1,900 hectares remained under lease to the stateowned plantation company, Perseroan Terbatas Perkebunan Nusantara (Archipelago Plantations Ltd, PTPN). However, in 1970, the New Order government began consolidating plantations, and the governor issued an

\footnotetext{
${ }^{7}$ BPRPI was formed in 1953. Since then, it has conducted more or less organised occupations of plantations in and around Medan.
}

eviction order and transferred Tanjung Gusta's smallholder land to the company. Smallholders protested and resisted, but in 1972, a major violent eviction was undertaken by PTPN's security outfit. Smallholders were left with less than 100 hectares, and BPRPI and its leaders had to lie low. The risk of being called 'communist' was very real. The movement practically dissolved, and its leaders could not be seen operating in public.

During the New Order, BPRPI was classified as an unruly organisation (Organisasi Tanpa Bentuk). Today, it is seen as a farmers' movement seeking to reclaim land. While BPRPI has gained an identity as an indigenous community through its long struggle, it is still not free from stigmatisation and violent criminalisation. When members of BPRPI began farming the land as smallholders in 1995, the plantation company PTPN IX (now PTPN II) organised violent intimidation, crop destruction, and arson. Violent evictions were commonplace, and the criminalisation of villagers' occupation of the land led to the imprisonment of their leaders. As late as 1999, around two thousand PTPN II employees-together with police officers and thugs from Medan's redoubtable gangs-were mobilised to burn the crops and houses of Tanjung Gusta's residents.

When the plantation's lease expired in 2000, it was not renewed. Consequently, the legal foundation for the plantation and the PTPN II's land control ceased to exist. Since that moment, the land was in legal limbo. Still, the plantation continued to operate. Others seemed ready to take over

${ }^{8}$ In 2016, BPRPI was active in 24 different land occupations in North Sumatra covering an area of 2,300 hectares. 
others. On several occasions, businessmen-flanked by bodyguards from different gangs-approached the smallholders of Tanjung Gusta to inform them that they had acquired the land from government; they never produced evidence of their claims. In the meantime, large numbers of people had migrated to the urban Medan, including Tanjung Gusta.

In 2002, when the Governor of North Sumatra announced the future release of 5,873 hectares of plantation land, desires were further stimulated. Although the location and intended beneficiaries remained unknown to the public, the announcement still motivated the people of Tanjung Gusta as well as thousands of others in Medan to claim that the land they controlled would be released. BPRPI was resurrected for a moment, convinced that its members land would be part of the 5,873 hectares. ${ }^{9}$ It believed that the 315.9 hectares of Tanjung Gusta would be included in the thematic map that would be released through SK42/HGU/BPN 2002 on 29 November 2002.

BPRPI members quickly occupied some 240 hectares of the plantation. However, PTPN II, supported by the plantation workers' union and Pemuda Pancasila (one of the most notorious paramilitary youth organisations), violently wrested back the land and evicted its occupants before they had time to settle. ${ }^{10}$ In subsequent years, occupations and

${ }^{9}$ The BPRPI homepage refers to this land as rightfully belonging to its members, and to the process as a scam (Anwar, 2008).

10 According to BPRPI's leaders, occupants were promised an alternative site, but it turned out to have already been settled.

11 The certificates read: Pemangku adat masyarakat adat Rakyat Penunggu Indonesia. Di evictions followed each other in close succession. Frequently, houses were torched, and whoever was considered a village leader could be arrested, beaten up, or worse. By 2011, smallholders in Tanjung Gusta, organised through BPRPI, held a total of 127 hectares of land. This land was still in legal suspension. Like most land in Indonesia, it was state land; however, with the plantation lease expired and no other rights being officially issued by the National Land Agency, recognition of possession had to come from elsewhere. This is where legalisation strategies became important and took shape.

BPRPI began to issue its own land certificates to its members in 2012. ${ }^{11}$ By 2016 , over 600 certificates had been issued by the movement. The certificate came at a price: Rp 200,000 (15 US\$). Each certificate had the names of the neighbours and the location of the plot. The plot was modest, some $1,700 \mathrm{~m}^{2}$, because as Medan had grown the smallholdings had continuously been subdivided, and the BPRPI-controlled part of Tanjung Gusta had become almost entirely urban. Certificates were used when plots changed hands, and often plotholders would sell off part of their land to newcomers and then go to BPRPI to have the certificates updated. Initially, BPRPI would vet new citizens in Tanjung Gusta, but increasingly land changed hands without the organisation's involvement, creating something of a clandestine land

bawah Panji-panji. Badan Perjuangan Rakyat Penunggu Indonesia. Lembaga Adat Rakyat Penunggu. Tanda bukti hak. [Indigenous peoples of Rakyat Penunggu Indonesia. Under the Banners of BPRPI. Proof of rights]. Document in private possession. 
market of the second order. The Indonesian government did not recognise BPRPI's land claims, and members did not abide religiously by the organisation's rules; they simply operated as if the land was theirs and used BPRPI's symbols and documents as valid proof in their transactions. In essence, the certificates invoked BPRPI as the authoriser, and in Tanjung Gusta the organisation was able to muster sufficient credibility as representing bona fide property rights.

Property was only one part of BPRPI's legalisation strategy, however. The organisation also tried to have Tanjung Gusta residents registered in the 2014 national census, but they were instead registered in a nearby village in Deli Serdang. Infrastructure was one of BPRPI's major concerns. Over the years, it had proved impossible to properly bring electricity to the area. In the 1990s, some residents had surreptitiously connected to the city power lines. In 1998, BPRPI offered membership and two plots of land to two engineers from the electricity company, and the neighbourhood was added to the grid and all houses were equipped with metres. BPRPI also had some of the roads in Tanjung Gusta paved, and-much to the delight of the BPRPI leadership-one street soon featured on GoogleMaps. An increasing number of small shops opened, and an official post office, official stops for ojeks (motorcycle taxis) and angkots (micro busses) also appeared. The

12 In Tanjung Gusta, BPRPI even created a boxing ring wherein culprits who were unable to pay their fines would fight each other. Ideally, the money raised by betting on the outcome would go toward paying the fine. When we inquired, this ring had only been used a couple of times. organisation built a cemetery as well as a prison cell for handling conflicts between neighbours. $^{12} \quad$ Furthermore, two kindergartens, with the memorable names Perjuangan (Struggle) and Karismatik (Charismatic), were opened to educate future generations. In 2014, BPRPI opened a new office in a two-story building in Tanjung Gusta. For the opening ceremony, it managed to invite Governor Gatot Pujo Nugroho, who signed the foundation stone and thereby bestowed some officialdom on the event, the movement, and its achievements. ${ }^{13}$ Fundraising took place within the movement.

The quest for recognition of the right to reside in Tanjung Gusta and control land peaked when the indigenous movement AMAN decided to hold its congress in the neighbourhood in 2017. Many delegates were hosted privately by local residents. The much-publicised event indicated that BPRPI represented indigenous peoples (in the broadest sense of the term) and had friends in high places. ${ }^{14}$

In 2017, BPRPI controlled approximately 310 hectares in Tanjung Gusta. Legally, the area of the old plantation, Helvetia, was mostly a no-man's land. PTPN's lease had lapsed almost 20 years previously, and though the company still operated on some of the land, chunks had been taken by BPRPI, developers, and a mix of gangs. One BPRPI organiser tried to explain: 'There are many states [negara] here. Pemuda Pancasila, IPK, AMPI, and

${ }^{13}$ The governor was later convicted of multiple graft cases and sentenced to six years imprisonment (Gunawan, 2016, 2017).

14 It was even expected that Indonesia's president, Joko Widodo, would grace the gathering with a visit. However, this never happened. 
PTPN. So, this is why we also claim to be state. We also claim the land (anonymous interview, November, 2016). In its $9^{\text {th }}$ congress, BPRPI issued a resolution and recommendation urging the Village Government to formally establish Kampong Rakyat Penunggu since the community had fulfilled the administrative requirements to become recognised as a village.

While BPRPI had initially occupied the land in Tanjung Gusta for small-scale peasant farming, it was effectively becoming an organisation of city-dwellers. Legally, according to government authorities, BPRPI and the community in Tanjung Gusta remained invisible. No documents from the National Land Agency acknowledged their claims, and no taxes were paid for houses or land; at the same time, there was no social contract with the government suggesting that land in the area would be part of the mythical 5,873 hectares that would be released. At the same time, the governance of the neighbourhood bespoke the strong visions and beliefs of the community. A meticulously kept land record system, tied to membership and other benefits, made community members ready to receive the rights they craved. They could easily become visible landholders, since they had already prepared the paperwork. Their landholding could become legal fact.

However, the development of the neighbourhood also presented danger to the movement. Land transactions were increasingly conducted without BPRPI's explicit certification. It remains to be seen whether the legalisation of these transactions without the recognition of an authorising institution will eventually impugn on the solidity of members' land claims.

\section{Conclusion}

Peasant and indigenous movements have tried to establish land registries and administrative procedures, and have had important political figures recognise their claims. They have tried to become legally and bureaucratically visible and produce maps to document their long presence. People who live on occupied plantation land have acted in anticipation of government recognition of their claims by organising their settlement in conformity with their ideas of formal government norms. People have tried to create legal facts through their repertoire of legalisation strategies. Different kinds of citizens have different modes of accessing the law. It is not merely the weapon of the powerful, or government, but also, somehow and sometimes, a weapon of the weak (Scott, 1985). People have improvised, not to act in illegality, but rather to access what they believe is legally theirs with the government's legal visibility and recognition, if not blessing. In all its technical illegality, such counterfeit legalisation does not undermine the ideas of the state, law, or rights. It underpins them.

The history of Tanjung Gusta and BPRPI shows a series of achievements in the face of adversity. The $5^{\text {th }}$ AMAN Congress has offered a means of strengthening the recognition of the community and its efforts to legalise land access. Nonetheless, the indigenous people of BPRPI Kampong Tanjung Gusta continue to face several challenges.

First, it is necessary to ensure that the reclaimed land is accessible to the weakest and most deserving groups. In many cases, the authors noted that groups or individuals benefitted disproportionately from the social movement's achievements. The 
organisation of peasant and indigenous peoples' movements to ensure justice and comprehensive adherence will be tested with time.

Secondly, the progressive policies on the books must be implemented effectively. President Joko Widodo introduced the Nawacita Programme during his first term, which sought to legalise access to 9.1 million hectares, redistribute assets, and mediate conflicts throughout Indonesia. Three legal instruments related to agrarian reformPerpres 88/2017 regarding the Settlement of Land Tenure in Forest Areas, Perpres 86/2018 regarding Agrarian Reform, and Inpres 8/2018 regarding the Postponement and Evaluation of Palm Oil Plantation Licensing and Increasing Palm Oil Productivity-have made it possible for land under expired plantation leases to be redistributed as part of agrarian reform. Unfortunately, however, these regulations have three weaknesses, i.e. (1) state plantation companies are excluded as objects of agrarian reform, (2) indigenous peoples are not explicitly identified as subjects of agrarian reform, and (3) local governments are often involved in agrarian conflicts and thus unable to mediate them. This is why the GTRA (Gugus Tugas Reforma Agraria, Agrarian Reform Task Force) of North Sumatra has been unable to encourage agrarian reform.

At the national level, no government institution is prepared to take the lead in handling agrarian conflicts. Government departments at all levels have a vested interest in the status quo, and the alliances between government, entrepreneurs, and financiers at the central and regional levels make policies that favour smallholders or landless people very unlikely. One may well imagine an autonomous institution led directly by the President to promote agrarian reform and properly carry out its mandate. However, the everyday operations of such an institution depends on actors at the implementation level. This is the real test for farmers and indigenous peoples' social movements and their struggle for the right to access and redistribute land.

\section{References}

Anwar, K. (December 4, 2008). Afnawi Noeh pejuang tanah adat. BPRPI. https://bprpi.wordpress.com/2008/12/04/afnawi-noeh-pejuang-tanah-adat/.

Bachriadi, D. (2010). Between discourse and action: agrarian reform and rural social movements in Indonesia post-1965. (Doctoral dissertation, Flinders University, School of International Studies). Flinders University Theses. https://theses.flinders.edu.au/view/4ae09ddd78af-485b-87b0-01147957c468/1.

Bachriadi, D., Lucas, A., \& Warren, C. (2013). The agrarian movement and emerging political constellations. In A. Lucas., and C. Warren (Eds.), Land for the people: The state and agrarian conflict in Indonesia (pp. 308-371). Ohio University Press.

Benda-Beckmann, K. von. (1981). Forum shopping and shopping forums: dispute processing in a Minangkabau village in West Sumatra. The Journal of Legal Pluralism and Unofficial Law, 13(19), 117-162. https://doi.org/10.1080/07329113.1981.10756260. 
Benton, L. (2012). Historical perspectives on legal pluralism. In B. Tamanaha., C. Sage., \& M. Woolcock (Eds.), Legal pluralism and development: Scholars and practitioners in dialogue (pp. 21-33). Cambridge University Press.

Campbell, J. (2015). Conjuring property: Speculation and environmental futures in the Brazilian Amazon. University of Washington Press.

Damanik, E. (2016). Kisah dari Deli: Historitas, pluralitas dan modernitas. Kota Medan tahun 1870-1942. [Story from Deli: History, pluralism and modernity. The city of Medan, 18701943]. Simetri Publisher.

Das, V. (2007). Life and words: Violence and the descent into the ordinary. University of California Press.

Fauzi, N., \& Bachriadi, C. (2006). The resurgence of agrarian movements in Indonesia: Scholaractivists, popular education and peasant mobilization. Paper presented at the Land, Poverty, Social Justice and Development Conference, The Hague, 9-14 January 2006.

Fitzpatrick, D. (2006). Private law and public power. Tangled threads in Indonesian land regulation. In H. S. Nordholt., \& I. Hoogenboom (Eds.), Indonesian transitions (pp. 75113). Pustaka Pelajar.

Gunawan, A. (2016, November 24). Ex-N. Sumatra governor sentenced to 6 years in prison for corruption. The Jakarta Post. https://www.thejakartapost.com/news/2016/11/24/ex-nsumatra-governor-sentenced-to-6-years-in-prison-for-corruption.html.

Gunawan, A. (2017, March 10). Former North Sumatra governor gets four years for bribery in third case. The Jakarta Post. https://www.thejakartapost.com/news/2017/03/10/former-north-sumatra-governorgets-four-years-for-bribery-in-third-case.html.

Hadiz, V.R. (2010). Localising power in post-authoritarian Indonesia: A Southeast Asia perspective. Stanford University Press.

Holston, J. (1991). The misrule of law: Land and usurpation in Brazil. Comparative Studies in Society and History, 33(4), 695-725. https://doi.org/10.1017/S0010417500017291.

Ikhsan, E. (2014). Communal land rights of Malay people in North Sumatera: Power, state and deulayatisasi. Indonesia Law Review, 358-373. http://dx.doi.org/10.15742/ilrev.v4n3.100.

Khairina, W. (2013). Konflik agraria masyarakat Desa Pergulaan VS PT. PP London Sumatera Indonesia Tbk. Kab. Serdang Bedagai, Sumatera Utara [Agrarian Conflict between the Village Community of Pergulaan and PT. PP London Sumatra Indonesia Tbk. Kab. Bedagai Serdang, North Sumatra]. (Unpublished Master's Thesis). Universitas Negeri Medan, Medan.

Khairina, W. (2015). Petani kehilangan tanah: Strategi legalisasi perjuangan kasus konflik agraria di Desa Pergulaan, Kec. Sei Rampah, Kab. Serdang Bedagai, Sumatera Utara. [Farmers losing land: The strategy and legal struggle in the case of agrarian conflict in Pergulaan Village, Sei Rampah District, Bedagai Serdang Regency, North Sumatra.] Medan, HaRI. 
Krier, J. (1994). Displacing distinction: Political processes in the Minangkabau backcountry (Doctoral thesis). Harvard University.

Kunz, Y., Hein, J., Mardiana, R., \& Faust, H. (2016). Mimicry of the legal: translating de jure land formalization processes into de facto local action in Jambi province, Sumatra. Austrian Journal of South-East Asian Studies, 9(1), 127146. https://doi.org/10.14764/10.ASEAS-2016.1-8.

Langenberg, M. van. (1982). Class and ethnic conflict in Indonesian's decolonization process: A study of East Sumatra. Southeast Asia Program Publications at Cornell University.

Lucas, A. \& Warren, C. (Eds.). (2013). Land for the people: The state and agrarian conflict in Indonesia. Ohio University Press.

Lund, C., \& Rachman, N. F. (2016). "Occupied!": property, citizenship, and land in rural Java. Development and Change, 47(6), 1316-1337. https://doi.org/10.1111/dech.12263.

Lund, C. (2014). Of what is this a case? Analytical movements in qualitative social science research. Human Organization, 224-234. https://doi.org/10.17730/humo.73.3.e35q482014x033|4.

Lund, C. (in press). Nine-tenths of the law: Enduring dispossession in Indonesia. Yale University Press.

McCarthy, J., \& Robinson, K. (Eds.). (2016). Land and development in Indonesia. Searching for the people's sovereignty. ISEAS.

Mitchell, T. (2002). Rule of experts: Egypt, techno-politics, modernity. University of California Press.

Moore, S. F. (1987). Explaining the present: Theoretical dilemmas in processual ethnography. American Ethnologist, 14(4), 727-736. https://doi.org/10.1525/ae.1987.14.4.02a00080.

Pelzer, K. (1957). The agrarian conflict in East Sumatra. Pacific Affairs, 30(2), 151-159.

Pelzer, K. (1978). Planter and peasant: Agrarian struggle and the colonial policy in East Sumatra, 1863-1947. 'S-Gravenhage: Verhandlingen van het Koninklijk Instituut voor Taal-, Land-, en Volkenkunde.

Pelzer, K. (1982): Planters against peasants. The agrarian struggle in East Sumatra, 1947-1957. 'S-Gravenhage: Verhandlingen van het Koninklijk Instituut voor Taal-, Land-, en Volkenkunde.

Rachman, N.F. (2011). The resurgence of land reform policy and agrarian movements in Indonesia (Doctoral thesis, University of California). California Digital Library. https://escholarship.org/uc/item/87s5s84g\#main.

Rasmussen, M.B., \& Lund, C. (2018). Reconfiguring frontier spaces: The territorialisation of resource control. World Development, 101, 388-399. https://doi.org/10.1016/j.worlddev.2017.01.018.

Reid, A. (1979). The blood of the people. Revolution and the end of traditional rule in Northern Sumatra. Oxford University Press. 
Rose, C. (1994). Property and persuasion: Essays on the history, theory and rhetoric of ownership. Westview Press.

Scott, J. (1985). Weapons of the weak: Everyday forms of peasant resistance. Yale University Press.

Stoler, A. L. (1985a). Capitalism and confrontation in Sumatra's plantation belt, 1870-1979. Yale University Press.

Stoler, A. L. (1985b). Perceptions of protest: Defining the dangerous in colonial Sumatra. American Ethnologist, 12(4), 642-658. https://doi.org/10.1525/ae.1985.12.4.02a00030.

Stoler, A. L. (1988). Working the revolution: Plantation laborers and the people's militia in North Sumatra. The Journal of Asian Studies, 47(2), 227247. https://doi.org/10.2307/2056166.

Wilson, I. (2015). The politics of protection rackets in post-New Order Indonesia: Coercive capital, authority and street politics. Routledge.

Winayanti, L. (2010). Community struggles for land in Jakarta: A case study of kampung community struggle to obtain security of tenure. Lambert Academic Publishing. 